Revista de Dialectología y Tradiciones Populares, vol. LXV, n. ${ }^{\circ}$ 1, pp. 255-288, enero-junio 2010, ISSN: 0034-7981, eISSN: 1988-8457, doi: $10.3989 /$ rdtp. 2010.007

\title{
Los caminos del Wallmapu (País mapuche)
}

\author{
The Ways of Wallmapu \\ (Mapuche Country)
}

\author{
Beatriz Vitar \\ Departamento de Historia de América \\ Universidad de Sevilla
}

\section{RESUMEN}

La autora presenta los principales rasgos del complejo fenómeno de revitalización mapuche en Argentina y Chile, concentrándose en la dimensión política del proceso en el ámbito chileno. En este último, la reafirmación étnica y lingüística ha conducido a la formación de un movimiento nacionalista mapuche, que aspira al reconocimiento de esta comunidad como una "nación" diferenciada por parte del Estado chileno. Pero este nacionalismo no puede entenderse haciendo abstracción de las condiciones generales en los países en que viven los mapuches, así como en otros (v. g., en Bolivia y en España).

Palabras clave: Chile, Argentina, País mapuche, Tradiciones culturales, Territorialidad histórica, Capitalismo transnacional, Revitalización étnico-lingüística.

\section{SUMMARY}

The author discusses the salient features of the complex phenomenon of Mapuche revitalization in Argentina and Chile, focusing on the political dimension of the process in the Chilean context. Here the ethnic and linguistic assertion is a key component in the emergence of a Mapuche nationalist movement, which calls for the Chilean Government's recognition of the Mapuche people as a different "nation." Such nationalism notwithstanding, Mapuche revitalization cannot be understood if taken out of the general conditions in the countries in which the Mapuche live, as well as in others, such as Bolivia and Spain.

Key Words: Chile, Argentina, Mapuche Country, Cultural Traditions, Historical Territories, Transnational Capitalism, Ethnico-linguistic Revitalization. 
INTRODUCCIÓN. LA EMERGENCIA ÉTNICA EN AMÉRICA LATINA

"La guerra mapuche sacude Chile", rezaba un titular del diario argentino La Nación de agosto de 2009, con relación a las protestas por el asesinato de un joven comunero en un enfrentamiento con carabineros ${ }^{1}$. Detrás de esta noticia, anunciada con tintes sensacionalistas, se escondía una larga historia que arranca en los tiempos coloniales y que hoy, en las vísperas de las celebraciones del Bicentenario de la independencia americana, impone reflexionar acerca de esas naciones "imaginadas" (Anderson 1993), construidas en torno a un ideal civilizador que excluyó a los habitantes autóctonos, identificados con la barbarie. Son estos mismos pueblos los que ahora experimentan un proceso de redefinición de su identidad colectiva, recorriendo las sendas que conducen a su consolidación como nación. Los mapuches constituyen un ejemplo cabal de ello.

Desde las últimas décadas del siglo xx, una conjunción de factores ha dado lugar en América Latina a los movimientos de revitalización étnica y lingüística, formando al presente parte de la realidad político-social de varios países del Continente. Este fenómeno se manifiesta en el rescate de elementos de la cultura tradicional, aunque a través de una reformulación identitaria que responde a un nuevo contexto en lo político, económico y social y a una dinámica de interacción con diferentes actores. En el caso mapuche, la reemergencia étnica se plasma esencialmente en la demanda de restitución de sus territorios históricos, "ocupados" por las repúblicas criollas en el siglo XIX, y, de modo correlativo, en la reclamación de su derecho a la autodeterminación y al autogobierno. Reivindicaciones estas que se fundan en el cuestionamiento de las nuevas repúblicas nacidas del proceso independentista, inventadas (Fernández Bravo 2000) sobre la base de la exclusión indígena; un proceso susceptible de revertirse en una "inclusión" determinada sobre la base de la "exclusión" — valga el juego de palabras- de sus características étnico-culturales diferenciales para diluirse en una misma identidad cultural común o ser nacional construido en torno al lema del progreso (Quijada et al. 2000: 31).

${ }^{1}$ Cuerpo de policía de Chile, dependiente del Ministerio de Defensa Nacional. Constituido bajo el lema de "Orden y Patria", tiene como funciones el mantenimiento de la soberanía nacional, el orden público y el cumplimiento de las leyes. El suceso al que hago referencia, ocurrido el 12 de agosto de 2009, motivó una declaración de condena a la actuación policial y de apoyo al pueblo mapuche por parte de miembros de la comunidad académica de Chile, entre los que se encuentran algunos de los autores citados en estas páginas; los firmantes de dicho documento reconocían al "Gulumapu" (o "Ngulumapu") como el "territorio histórico del Pueblo Mapuche" (http://argentina. indymedia.org/news/2009/08/687829.php). 
A escala mundial, el resurgimiento de las minorías étnicas representa un rechazo a las tendencias homogeneizadoras de la Globalización, enarbolando la bandera de la cultura y las tradiciones ancestrales como base de sustentación de sus reclamos a los Estados nacionales. Así pues, un factor decisivo en el desencadenamiento del fenómeno de "re-etnificación" ha sido la mundialización económica y la implantación de políticas neoliberales, que afectaron singularmente a los sectores sociales menos favorecidos - entre ellos los denominados "pueblos originarios" - a través de emprendimientos de gran alcance que, como ocurrió con muchas comunidades mapuches, condujeron al desalojo de sus tierras. Paralelamente, la expansión neoliberal no sólo ha dado pie a la paradójica "globalización" de los propios procesos de revitalización étnica sino que ha fomentado también redes solidarias entre los diversos movimientos, a un punto tal que en el ámbito latinoamericano puede hablarse de una "agenda indígena transnacional" (Warren 1999: 148).

Los años previos a la conmemoración del V Centenario y las reacciones críticas en torno a ese evento propiciaron la emergencia de la "resistencia" indígena, tal como lo ilustran el levantamiento indígena de Ecuador (1990) y el movimiento zapatista iniciado en Chiapas (México) en 1994 (Bengoa 2007: 93-120). En Chile y Argentina, la re-etnificación se desarrolló paralelamente a los procesos de transición democrática iniciados con posterioridad a los regímenes de facto instaurados en dichos países en 1973 y 1976, respectivamente. Fundamentalmente, las demandas indígenas se han visto reforzadas y legitimadas en las dos últimas décadas del siglo pasado por los pronunciamientos de organismos internacionales, como es el caso de la Convención 169 (1989) de la OIT y la Declaración de la ONU (1994) sobre el reconocimiento de los derechos colectivos de los pueblos originarios. Estas resoluciones sirvieron de "modelo" para adaptar el marco jurídico de los Estados latinoamericanos al reconocimiento de la preexistencia étnica y cultural de los pueblos indígenas y de su derecho a la autodeterminación y restitución de las tierras comunitarias. Argentina ratificó el Convenio de la OIT en 1992, recogiendo sus determinaciones en la reforma constitucional de 1994, mientras que en Chile —que lo ha formalizado en 2008- aún queda pendiente el ajuste de la legislación interna a las estipulaciones de aquel acuerdo internacional, cuestión sobre la que la dirigencia mapuche ha manifestado su escepticismo (Quilaqueo 2009). Frente a los obstáculos que aún se experimentan en los dos países que albergan población mapuche en lo referido al reconocimiento pleno de sus derechos, el fenómeno de revitalización étnica ha alcanzado su máxima expresión en la vecina Bolivia, donde Evo Morales ha sido reelecto presidente en diciembre de 2009.

Los mapuches representan el contingente más numeroso dentro del conjunto de pueblos "originarios" de Chile y Argentina, siendo reconocidos en 
la actualidad como uno de los grupos más comprometidos en la lucha por el reconocimiento pleno de sus derechos civiles y políticos. Sin embargo, el contexto en el que se desenvuelve el fenómeno de revitalización étnica y lingüística en los citados países es muy diferente al de la vecina Bolivia, donde más de la mitad de su población es indígena. Por lo que se refiere al resurgimiento indígena en Chile, si bien comenzó a cobrar fuerza en los años de la transición política, un antecedente importante se encuentra en los tiempos de Salvador Allende. En el marco de la "efervescencia social" que caracterizó a su gobierno, la comunidad mapuche vivió algunas experiencias de recuperación identitaria (Gissi 2004a), aunque tal proceso habría de sufrir los embates de la dictadura de Pinochet para luego renacer lentamente desde mediados de los años 1980. Desde entonces, el fenómeno de revitalización ha ido creciendo progresivamente en sus diversas facetas, incluida la elaboración de propuestas de autodeterminación a través de la constitución y el reconocimiento de la nación o "País Mapuche". Estas reivindicaciones no se han materializado aún en hechos concretos, lo que, por otra parte, podría verse afectado en el futuro, a la vista de los recientes comicios celebrados en Chile ${ }^{2}$. La situación actual del movimiento mapuche está marcada por las acciones en pro de la recuperación de tierras, dando lugar a continuos enfrentamientos con las fuerzas de seguridad chilenas y la consecuente detención de dirigentes. Sucesos similares se registran actualmente en zonas de asentamiento mapuche en Argentina, país en el que la "cuestión indígena" comenzó a adquirir relevancia a partir de la transición política iniciada en 1983; sobre todo merced a la atención prestada por los organismos de derechos humanos al estado de la población indígena, lo que se plasmó en la reforma constitucional de 1994 (Kropff 2005: 104). La nueva Carta Magna define a Argentina como "nación pluriétnica", a la vez que reconoce —en su artículo 75, Inc. 17- los derechos colectivos de los pueblos originarios, en especial la propiedad comunitaria de las tierras que ocuparon ancestralmente. Este reconocimiento ha supuesto un notable avance para los indígenas en cuanto a constituirse como "sujetos políticos por derecho propio" (Vom Hau y Wilde 2009: 3, 7).

El movimiento de revitalización mapuche se define en torno a unos ejes básicos, determinados por la reclamación de tierras (usurpadas por los Estados nacionales en el siglo XIX y, en la actualidad, objeto de explotación por empresas transnacionales), la defensa de sus tradiciones culturales (frente

${ }^{2}$ En las elecciones celebradas en diciembre de 2009 y enero de 2010, el candidato de la derecha chilena, Sebastián Piñera, ganó con clara ventaja frente a Eduardo Frei, candidato de la Concertación, alianza de partidos que gobernaba el país desde hacía dos décadas. 
a las políticas asimilacionistas) y el reconocimiento político como "nación" (Samaniego Mesías y Ruiz Rodríguez 2007: 26-27). En la coyuntura presente, las demandas se dirigen sobre todo a la restitución y autogobierno de los territorios históricos mapuches, sobre la base de una estrategia discursiva que apela al rescate de la cultura y la especificidad étnica y lingüística, así como al resarcimiento del despojo territorial y asimilación forzosa sufridos en virtud del modelo neo-colonial adoptado por la elite criolla en el proceso de formación nacional.

En lo que respecta al proceso de revitalización en su faceta política (la reivindicación de un "País" o "Nación" Mapuche), su complejidad exigiría un largo desarrollo que, dados los límites de este ensayo, se circunscribirá a la presentación de los principales rasgos de dicho fenómeno y a esbozar algunas interpretaciones a la luz de las principales aportaciones teóricas sobre los nacionalismos, atendiendo, claro está, a las especificidades del caso analizado, es decir, a las de un pueblo indígena sin duda preexistente a la constitución de los Estados nacionales de Chile y Argentina. El reencuentro con ese largo pasado está muy presente en las narrativas justificadoras del movimiento, así como en las de algunos de sus detractores; pero, en la práctica, no se trata de una vuelta a ese pasado, sino de construir un presente y un futuro propios. Con muchas y diversas facetas, y de varias voces, el movimiento no puede separarse del doble contexto nacional e internacional en el que se desenvuelve, del cual depende en muy gran medida. Y frente a quienes anteponen la solidaridad interna - la que exige ser miembros de un "pueblo" o "nación" unida- a las relaciones con formaciones o instancias sociales o políticas (o aun religiosas) no mapuches en los países afectados, están quienes consideran tales relaciones como necesarias con vistas a los objetivos liberadores del movimiento, cuando no como alternativa a una vieja pertenencia que se desea superar o trascender.

Los diversos aspectos de la "cuestión mapuche" ${ }^{3}$ han sido objeto de un considerable número de estudios, referidos tanto al ámbito chileno como al argentino. Me centraré en especial en el primero, aunque sin ánimo de ratificar esas fronteras que "nos partieron por la mitad" — según la expresión utilizada por Ancán Jara (2003: 26) — para aludir a la demarcación territorial de los respectivos Estados nacionales en el siglo XIX.

\footnotetext{
3 Samaniego Mesías y Ruiz Rodríguez hablan de "cuestión mapuche" y no de "problema indígena”, en tanto que éste es algo que incumbe al Estado y a la sociedad winka (nombre que los mapuches dan a los chilenos y a los no indígenas) por su incapacidad histórica de "resolver" las relaciones con los mapuches (2007: 14).
} 
Las noticias coloniales sobre este grupo indígena, un caso de las denominadas "sociedades de cacicazgos", proyectan la imagen de un pueblo guerrero y resistente a la dominación, sujeto a la conocida trilogía clasificatoria sin rey, sin fe y sin ley tan en boga en la literatura de la época. Con estos pueblos bárbaros, sin embargo, no sólo se mantuvieron guerras sino también parlamentos y tratados de paz, recibiendo el tratamiento de naciones. Como bien señala Weber (1998: 162), durante el período de los Habsburgo se instauró un marco jurídico dentro del cual los mapuches -o "araucanos" - tuvieron garantizado un territorio propio al sur de la frontera del río Bío-Bío en virtud del Tratado de Quillín, firmado por las autoridades coloniales y los líderes araucanos en 1641. Si bien el conflicto fronterizo persistiría durante todo el período colonial, a fines del siglo XVIII (bajo los Borbones) "los españoles implícitamente reconocían que el territorio araucano, el Estado de Arauco, gozaba de autonomía" (ibid:: 163). Además, los acuerdos celebrados reconocían su carácter de nación fronteriza (la sola mención de una "frontera" suponía la aceptación de un límite territorial a la expansión colonial), cimentando una tradición pactista mediante la cual la Corona aseguraba a los grupos araucanos "derechos más amplios que los otorgados a otros indígenas" (ibid.: 162). En la etapa de la emancipación, la fidelidad a los pactos establecidos con la monarquía española llevó a los mapuches a aliarse con las fuerzas realistas para combatir a la insurgencia criolla. En el caso argentino, el proceso colonial registró características similares, con períodos de guerra fronteriza y otros bajo la vigencia de acuerdos o tratados de paz, en una relación secular en la que se alternaron — aunque en términos más ventajosos para el poder español— "dominancia y resistencia en cada uno de los contendientes" (Bechis 2008: 362).

En el siglo XIX, el movimiento independentista criollo incluyó al mundo indígena con fines utilitarios, dada la necesidad de reforzar los márgenes de las nuevas naciones. Incluso, las exigencias del proceso emancipador promovieron el enaltecimiento de los mapuches en la retórica "patriota" (v. g., la idealización de la figura de Lautaro en Chile), aunque, una vez estabilizada la nueva nación, los indígenas pasaron a ser los salvajes que obstaculizaban el avance de la modernidad (Samaniego Mesías y Ruiz Rodríguez 2007: 23). Como hoy ocurre con la globalización económica, los dictados del nuevo modelo impuesto a las ex colonias hispánicas por los países industrializados, disfrazados bajo el lema Civilización o barbarie, se tradujeron en la expansión de las fronteras y la ocupación de las tierras indígenas para llevar a cabo la explotación minera y agro-ganadera. Así, bajo la consigna de "modernidad y progreso", los procesos de construcción na- 
cional en Chile y Argentina estuvieron acompañados de las operaciones militares conocidas, en uno y otro caso, como "Pacificación de la Araucanía" y "Campaña del Desierto", las cuales ocasionaron a los mapuches la pérdida de sus tierras. Tras la acción militar, en Chile se procedió al reparto de la población indígena en reducciones, a las que se otorgó una porción delimitada de tierras mediante "títulos de merced" (Saavedra Peláez 2002: 5960), distribuyéndose el resto del territorio entre colonos chilenos y europeos. En Argentina, la mencionada acción militar contra las poblaciones nativas implicó también la apropiación de tierras por parte del Estado, ampliándose de este modo el espacio productivo agro-ganadero con destino a la exportación, a la vez que se dispuso el realojamiento de los grupos sobrevivientes en áreas marginales sin interés productivo (Radovich y Balazote 1999). Por lo demás, el dominio de las naciones criollas supuso para las comunidades mapuches —al igual que para otros grupos étnicos - el fin de su existencia como entidades política y culturalmente diferenciadas (Bechis 2008: 23-24). La decidida política homogeneizadora implementada por el Estado liberal en el siglo XIX coadyuvó a un tipo de definición identitaria expresada en términos de una "nación de raza blanca y cultura europea", con exclusión de otros componentes étnicos (indígenas, africanos). Se trata de una "interpretación de la propia nacionalidad" que en buena medida persiste hasta hoy en el imaginario colectivo (Quijada et al. 2000: 10).

Dentro del proceso de transformación de las jefaturas mapuches en el siglo XIX, pasando del liderazgo bélico a otro más estable como resultado de la intensificación de la vía diplomática en las relaciones con los winka, hubo intentos de unificación del poder político a través de la figura de un "rey o jefe supremo" (ibid:: 205). En 1861, durante la pacificación de la región araucana, por iniciativa de algunos lonkos (líderes), los mapuches coronaron a Orélie-Antoine de Tounens como "primer" rey de la Araucanía, declarando su independencia y anexando posteriormente a la Patagonia. El hecho de adoptar los mapuches un elemento externo a su cultura (como lo era una monarquía hereditaria) podría explicarse tal vez en función de esa "flexibilidad adaptativa" que ha destacado Boccara (1999) respecto de esta etnia, siendo un rasgo que mantendría su continuidad, a tenor no sólo del abandono de algunas viejas costumbres "por necesidad de una vida nueva" - como observaba un etnógrafo a comienzos del siglo xx (Guevara 1913: 5)—, sino también de las aspiraciones nacionalistas actuales.

A pesar de la efímera existencia de aquel reino araucano-patagónico en virtud de la rápida intervención del Gobierno de Chile, el episodio quedó grabado como un hito en la lucha por la independencia mapuche, manteniéndose aún una "Casa Real" en el exilio (Francia) cuyo representante actual, el Príncipe Felipe de la Araucanía y Patagonia, dirige proclamas en favor 
de los "derechos soberanos" de su pueblo ${ }^{4}$. Un reino negociado, como esta aventura touneniana, supuso reinventar tradiciones y hacerse con un monarca de cara al avance militar chileno sobre los territorios mapuches en el siglo XIX.

"Lo que hace a la nación es el pasado", ha apuntado Hobsbawm (2000: 173), y hoy los hechos históricos se constituyen en fuente legitimadora de las reivindicaciones de un "País Mapuche": ahí están el Pacto de Quillín y la frontera del Bío-Bío, más todos los acuerdos posteriores firmados con la Corona española y, también, la constitución de ese "Reino de la Araucanía y la Patagonia" - un suceso detrás del cual se hallaban los planes expansivos de Napoleón III de Francia (Bechis 2008: 205)—, como prendas de la existencia de un territorio autónomo mapuche.

\section{POBLACIÓN, TERRITORIO E IDENTIDAD: EL IMPACTO DE LA GLOBALIZACIÓN}

La definición de un espacio propio del "País Mapuche" (Wallmapu), compuesto por regiones que se extienden a uno y otro lado de la cordillera andina, es un punto de partida clave en el proceso de reivindicación nacionalista. Si una base territorial con fronteras precisas asume una importancia capital en todo proyecto de nación, el "desmembramiento" de la población mapuche — considerando su dispersión en territorios de Chile y Argentina- exigiría, a juicio de los pensadores del "País mapuche", consolidar las áreas de mayor concentración de habitantes de este origen (en concreto la Araucanía, con capital en Temuco) y promover al mismo tiempo el retorno de los que emigraron a los centros urbanos (Naguil 2005: 6). Así, la cuestión del territorio asume una importancia capital, semejante a la que - precisamente - mantuvo en el proceso de formación de las naciones hispanoamericanas tras su independencia de España (Quijada et al. 2000: 42). Conforme a lo señalado por Vom Hau y Wilde (2009), también resulta aquí pertinente puntualizar que en la reforma constitucional argentina de 1994, si bien se formalizó el reconocimiento de los derechos colectivos de los pueblos originarios, se habla en ella del derecho a la "tierra", pero no de "territorio"; razón ésta por la que pueblos como los diaguitas y mbyaguaraníes —estudiados por los autores citados — reclaman la aplicación plena del Convenio 169 de la OIT en orden a la recuperación de sus territorios,

${ }^{4}$ Véase, por ejemplo, "Mensaje de Wiñoy Xipantu [Año Nuevo] 2009 del Príncipe Felipe de Araucanía y Patagonia a la Nación Mapuche”. Casa Real de Araucanía y Patagonia: http://www.mapuche-nation.org/espanol/html/reino/documentos/w-xipantu-07.htm. Esta monarquía en el exilio no está reconocida por ningún Estado, como tampoco lo fue el reino proclamado por Tounens. 
fundamentándose en el derecho que les asiste por su ocupación histórica y ser trascendental para la conservación de su identidad cultural (Vom Hau y Wilde 2009: 17).

El Wallmapu imaginado abarca las diferentes regiones en las que se distribuye la población mapuche en Argentina (Puelmapu) y Chile (Ngulumapu o Gulumapu), lo que suma más de un millón de personas, conforme a los últimos datos censales obtenidos en ambos países. En el caso de Chile, contabilizando los diversos grupos étnicos ${ }^{5}$, el total de pobladores indígenas que arrojó el censo de 2002 fue de 692.192 personas, cifra de la que un 87,31\% (604.349) correspondió a la etnia mapuche (Gissi 2004a). Se trataba de un número sensiblemente menor al obtenido en el censo de $1992^{6}$, que había dado como saldo un total de 927.060 mapuches dentro del territorio chileno; razón por la cual algunos estudios resaltaron la imprecisión en la formulación de las preguntas y la auto-censura que condujo a muchos a no reconocerse como indígenas ${ }^{7}$, al tiempo que otros llegaron a hablar incluso de un "genocidio estadístico" (Hernández 2003: 45).

Un 30\% de los mapuches de Chile habita en la Región Metropolitana, distribuyéndose el resto en otras áreas del territorio de la república. La zona de mayor concentración mapuche (con algo menos de 250 mil personas, según el censo de 2002) y la que actualmente presenta un protagonismo más marcado en cuanto a reclamos territoriales y acción política es la conocida como Ngulumapu o Gulumapu (que comprende las regiones de los Lagos, Araucanía y parte de la de Bío-Bío, incorporadas al Estado chileno a fines del siglo XIX); aparte de este territorio, se encuentra el Fütawillimapu o región sur del País Mapuche, habitada por los mapuche-williches (Naguil 2005). A su vez, dentro del conjunto mapuche existen otros subgrupos, como los pehuenches ("gentes del Pehuén") Bío, en la IX Región de Chile (Bengoa 2007: 124).

\footnotetext{
${ }^{5}$ La ley indígena de 1993 reconoció oficialmente la existencia de ocho etnias en el país (Naguil 2005): mapuche, aymara, rapa nui, atacameño, alacalufe, colla, quechua y yamana.

${ }^{6}$ En este censo la pregunta giró en torno a la identificación de los censados con uno de los grupos indígenas existentes en el territorio chileno, mientras que en el de 2002 se enfatizó sobre la pertenencia a uno de tales grupos.

7 Sobre las particularidades de ambos censos y en especial las deficiencias de la técnica censual aplicada en 2002, véase: "Reflexiones metodológicas en torno a los censos de 1992-2002 y la cuestión Mapuche", por M. Valdés (Wekull) en http://www.mapunet. org/documentos/mapuches/Ref_met_cen_1992-2002.pdf.

${ }^{8}$ El nombre "Pehuén" es el de una especie arbórea propia de las cordilleras del sur de Chile, conocida en español como araucaria (Bengoa 2007: 124). Los pehuenches, originariamente una etnia diferente, fueron "mapuchizados" a raíz de las migraciones mapuches a la zona cordillerana después de la invasión española (Mariotti 2004: 267).
} 
De entre las regiones habitadas por mapuches en Chile, la Araucanía (o IX Región, con un 26\% de población mapuche) es la que registra mayores índices de pobreza9 y una mayor concentración de población (predominantemente rural) que se "auto-identifica" como mapuche, definiendo una "alta correlación” entre ruralidad, etnicidad y pobreza (Gissi 2004a). La falta de recursos en la región fue generando un "constante" flujo migratorio hacia el área metropolitana, en la que la marginalidad y la pobreza propiciaron la "auto-segregación espacial" de los inmigrantes mapuches, fomentada también por el rechazo de los chilenos. Si bien estas circunstancias afectaron a los primeros en llegar, induciéndolos a una negación de sus orígenes étnicos, hoy las nuevas generaciones experimentan un proceso de reafirmación identitaria (Gissi 2004a: 9) que se nutre del nuevo contexto de revitalización indígena a escala continental, dando lugar al surgimiento de una nueva "cultura mapuche" en la Región Metropolitana ${ }^{10}$ (Gissi 2004a y 2004b). Ahora bien, la atomización espacial del pueblo mapuche a causa de las migraciones hacia las ciudades alteró "los conceptos de comunidad, de lof, de reducción" (Gissi 2004a: 6), a lo que debe añadirse la incidencia de la Ley 19.253 sobre tierras indígenas, por la que se crearon "comunidades" (equivalentes a los $l o f^{11}$ ) organizadas con criterios occidentales, con un presidente elegido por voto en lugar de la tradicional jefatura (hereditaria) del lonko ${ }^{12}$ (Latta 2005: 179).

El Puelmapu constituye la región este del Wallmapu y abarca básicamente las provincias argentinas de Neuquén, Río Negro y Chubut. Los mapuches de Argentina representan el grupo mayoritario dentro de los llamados "pueblos originarios", según datos oficiales recogidos en 2004-200513: de un total de 600.329 personas que se reconocían "pertenecientes y/o descendientes en primera generación de pueblos indígenas" (más de 30 censados), los mapuches sumaban 113.680. Como en el caso chileno, también hubo emi-

\footnotetext{
${ }^{9}$ En 1998 el 14,6\% de población en estado de pobreza se concentraba en la Araucanía, representando los mapuches un $80 \%$ de ese total (Gissi 2004a).

${ }^{10}$ Se trata, por lo demás, de procesos inherentes a los fenómenos migratorios, ya que las sucesivas generaciones van construyendo su identidad en el marco de las interacciones con la sociedad receptora.

${ }^{11}$ El lof es la unidad tradicional de familias, basada en el parentesco extenso (Latta 2005).

${ }^{12}$ Otro de los cambios surgidos en la jefatura fue la aparición de líderes femeninas (Latta 2005: 186).

${ }^{13}$ Encuesta Complementaria del Censo Nacional de Población, Hogares y Viviendas de 2001: http://www.indec.gov.ar/webcenso/ECPI/index_ecpi.asp. Encuesta Complementaria de Pueblos Indígenas. Resultados nacionales: http://www.indec.gov.ar/webcenso/ ECPI/pueblos/ampliada_index_nacionales.asp? $m o d e=00$.
} 
gración a los centros urbanos (ciudades de Patagonia y otras regiones de Argentina), concentrándose en las provincias de Neuquén, Río Negro y Chubut, Buenos Aires, La Pampa, Santa Cruz y Tierra del Fuego. De todas ellas, es la de Neuquén la que sobresale en el plano organizativo, que se remonta a los años 1970, a la vez que en las distintas ciudades patagónicas se asiste a un "activismo juvenil" mapuche. A través de éste, la revitalización étnica asume los rasgos típicos de un fenómeno urbano y generacional en el que se funden las tradiciones y los ingredientes de la cultura urbana y juvenil, definiéndose así un replanteamiento identitario que condensa muy bien la expresión "mapurbe" (Kropff 2005: 117-120).

Si bien la acción de los mapuches en Argentina no carece de importancia, el mayor peso numérico de esta etnia en el ámbito chileno le dota de un relieve más acusado a sus acciones reivindicativas. Los movimientos a uno y otro lado de la Cordillera están aunados en la lucha por la tierra, aunque no han terminado de cuajar en una propuesta autonómica común, en parte por las diferentes circunstancias en que se desenvuelve su andadura en un país y en otro.

La re-etnificación está íntimamente vinculada al impacto de la globalización económica, traduciéndose en denuncias contra el capital transnacional que explota importantes recursos naturales en los territorios originarios mapuches de Chile y Argentina, con el visto bueno de sus respectivos Gobiernos. La recuperación de tierras que pertenecían a las comunidades o lof, ocupadas por las empresas mineras, forestales ${ }^{14}$, agroindustriales y energéticas (Samaniego Mesías y Ruiz Rodríguez 2007: 26), representa el aspecto más "combativo" del fenómeno de revitalización, cuyo objetivo último es la consolidación del Wallmapu o "País Mapuche". En el caso argentino, la lucha emprendida por los mapuches contra la firma Benetton - poseedora de unas novecientas mil hectáreas en la Patagonia-, constituye un claro ejemplo de reafirmación étnica y defensa territorial frente a los avances del capitalismo transnacional. En este conflicto se acusó a la "Compañía de Tierras del Sud Argentino S. A.”, perteneciente a aquellos empresarios italianos, "de llevar a cabo una 'nueva conquista' de las tierras de los indígenas mapuches en la Patagonia", equiparándola a la "Campaña al Desierto" emprendida durante la presidencia de Julio A. Roca en el siglo XIX; ésta implicó un verdadero "genocidio", además de pérdidas territoriales (Briones y Ramos 2005). La movilización indígena contra la firma Benetton concitó la

\footnotetext{
${ }^{14}$ En 2004-2005, la industria forestal —uno de los "pilares" de la economía neo-liberal- incrementó sus exportaciones en un 33\%, previéndose hasta 2010 un ritmo sostenido que afectará a "100 mil nuevas hectáreas de bosque exógeno" (Samaniego Mesías y Ruiz Rodríguez 2007: 437, 439).
} 
adhesión de sectores no mapuches ante lo que se percibió como una "usurpación" de territorios por "extranjeros", transformándose así en un conflicto que implicó a otras "audiencias" (ibid.).

La defensa de la "territorialidad histórica", entendida como espacio en el que se recrea la identidad mapuche (ibid.: 419), constituye en consecuencia un argumento de peso para los reclamos de tierras que protagoniza esta etnia. Siendo además las zonas en reclamación las que hoy acusan el impacto negativo de la globalización económica desde el punto de vista ambiental, la defensa de la naturaleza refuerza sin duda la viabilidad de las propuestas mapuches con relación al reconocimiento de la autonomía territorial y autogestión de sus recursos, en la actualidad competencia de los Estados nacionales. La lucha contra la Globalización ha llegado a convertirse así en la "experiencia unificadora" subyacente a la construcción de las naciones, comparable a la función que tuvieron, por ejemplo, las guerras medievales de galeses, irlandeses y escoceses contra los ingleses en la formación de los correspondientes nacionalismos, según Hastings ${ }^{15}$ (en Fernández 2005: 78). En la conformación del discurso nacionalista mapuche juega un papel de consideración la existencia de una elite intelectual, integrada por miembros de la comunidad que han completado sus estudios universitarios - esencialmente en campos como la antropología o la historia- y que han obtenido así una capacitación y herramientas cognoscitivas indispensables para sus reivindicaciones ante los Estados nacionales o instancias gubernamentales locales (en el caso argentino), sobre lo que me detendré más adelante.

La búsqueda de la autonomía política y, de modo paralelo, el rescate de las formas de división "socio-territorial" (lof, rewe y ayllarewe) preexistentes al modelo reduccional establecido en el siglo XIX, supone el cuestionamiento del modelo de organización territorial del Estado (basado en la división en regiones, provincias y municipios) mientras pone sobre la mesa el derecho a la autogestión de sus recursos naturales (Boccara 1999: 47). No obstante, el acceso de dirigentes mapuches al gobierno local en varios municipios del sur de Chile (Bengoa 2007: 21) ha implicado un cambio significativo en las formas tradicionales de liderazgo, en razón de la incorporación a las estructuras de poder del mundo winka.

Los reclamos territoriales se enfrentan a una serie de obstáculos, como la vigencia del modelo "libremercadista" impuesto por la dictadura militar

\footnotetext{
${ }^{15}$ Hastings (2000) otorga una importancia crucial a la etnicidad y a las particularidades culturales (lengua, religión) en la construcción de las nacionalidades, frente a las tesis de los "modernistas", como Hobsbawm (2000) y Anderson (1993), quienes sostienen la idea de un nacionalismo basado en una reinvención de la tradición.
} 
en Chile, que arrasó con la propiedad comunitaria, es decir, con las tierras otorgadas a través de títulos de merced $^{16}$ (Samaniego Mesías y Ruiz Rodríguez 2007: 16). Aunque la división de tierras practicada en la época pinochetista ${ }^{17}$ fue resistida por muchos dirigentes mapuches, acabó convirtiéndose en la manzana de la discordia en el seno de algunas familias, ya que mientras se hizo efectivo el otorgamiento de títulos de propiedad a los miembros que vivían efectivamente en el campo, se excluyó de este reparto a los parientes emigrados a las ciudades (Martínez Neira 2008: 144).

A los conflictos generados por la parcelación de tierras se sumaron los suscitados por las represas hidroeléctricas construidas por la compañía española Endesa ${ }^{18}$ en el Alto Bío-Bío, que significaron el desalojo de cien comunidades pehuenches. El estudio de Latta (2005) sobre este caso muestra el juego de intereses de los diversos actores (mapuches, Estado, empresas, la sociedad chilena) y las consecuencias negativas de los planes desarrollistas estatales en lo inherente a las prácticas organizacionales mapuches, dado que la dinámica "proyectista" del modelo económico, como afirmara Foucault, apunta al fin último de formar "sujetos neoliberales" (en Latta 2005: 170).

\section{OtRos ASPECTOS DE LA REVITALIZACIÓN MAPUCHE}

La construcción de nuevas realidades comienza por el lenguaje mismo. En el fenómeno de revitalización de los pueblos originarios, se trata de renombrar la identidad colectiva. Como resultado de los procesos de reafirmación étnica en América Latina, de la negación a reconocerse como "indio" se pasó a asumir positivamente la condición de "indígena" (Bengoa 2007: 7, 12). En este sentido, Samaniego Mesías y Ruiz Rodríguez (2007: 14)

\footnotetext{
${ }^{16}$ En 1979 Pinochet decretó la división de la propiedad comunitaria indígena, entregando las parcelas a los cabezas de familia. La nueva ley indígena de 1993 (bajo el Gobierno de P. Aylwin) estableció a su vez un régimen de protección especial para estas tierras, prohibiendo su venta a los no indígenas, entre otras medidas (Bengoa 2007: 121-122).

${ }^{17}$ Con anterioridad a la dictadura pinochetista, la Reforma Agraria emprendida por Eduardo Frei y Salvador Allende no llegó a subsanar el despojo sufrido por los mapuches en el siglo XIX, al no concretarse la restitución de tierras "ancestrales" (Samaniego Mesías y Ruiz Rodríguez 2007: 419).

${ }^{18}$ Entre 1997 y 2004, la construcción de las represas Pangue y Ralco por parte de Endesa (nombre, a su vez, de la antigua compañía estatal chilena, la Empresa Nacional de Electricidad, privatizada por Pinochet) provocó una ola de protestas de los mapuchepehuenches. Un tercer emprendimiento (la represa de Corema) fue aprobada en septiembre de 2009, al superar la evaluación de impacto ambiental.
} 
inciden en la diferencia entre "indigenismo" (que "incorporó" a los indígenas como elementos pasivos) e "indianismo", término éste que viene usándose últimamente en estudios de diverso tipo. Sin embargo, dadas sus connotaciones generalizadoras, ambos términos son rechazados por las diferentes etnias, que prefieren recurrir a los nombres con los que se autodenominaron históricamente: quiché, mapuche, aymara, wichí, etc.

Paradójicamente, a la vez que la globalización económica fomentó los movimientos de revitalización en defensa de la cultura y las fronteras étnicas, otros procesos globales, como los experimentados en el mundo de la información, se han convertido en una herramienta clave para los programas étnico-reivindicativos. Bien podría compararse esta revolución tecnológica con el impacto de la cultura impresa (Print capitalism) en la consolidación de las lenguas vernáculas, destacada por Anderson (1993: 63-64) como uno de los pilares del nacionalismo (en Fernández 2005: 78). En este sentido, la creación de numerosas páginas Web, muchas de ellas bilingües, ha coadyuvado a difundir el fenómeno de revitalización étnica en una escala global, logrando una mayor concienciación y adhesiones a su causa. Las redes virtuales tienen un papel definido en la difusión del discurso nacionalista mapuche — hay un "País Mapuche" virtualmente visible, colgado en la reden pro de su reconocimiento como pueblo diferenciado, con derecho a un territorio y Gobierno propios. Sin embargo, los beneficios de esta revolución tecnológica no alcanzan a todos por igual, como ocurre en Chile con algunas comunidades con escasa o débil presencia en las redes globales, entre otras razones debido a su aislamiento geográfico (Latta 2005: 170-171). La situación afecta especialmente a las poblaciones mapuches de las zonas cordilleranas, cuyas dificultades topográficas las mantienen al margen de los circuitos de información (Mariotti 2004: 267).

Con relación al rescate de elementos culturales propios que persigue el movimiento de reafirmación étnica mapuche, la lengua adquiere un carácter prioritario. De este modo, paralelo al objetivo de lograr la autonomía territorial en un Estado descentralizado, existe el propósito de declarar el mapudungun (o mapuzungun, acorde con la fonética) lengua oficial del futuro "País Mapuche". La recuperación lingüística se convierte así en uno de los fundamentos de la nación mapuche, en un proceso comparable al de la consagración del uso del vasco y el catalán en lo que se refiere al proceso autonómico español. La revitalización del idioma se ha plasmado en gestos significativos, como el de utilizar la denominación originaria de los territorios del tal "País mapuche" (aspecto que también es dable observar, por ejemplo, en las Comunidades Autónomas españolas antes citadas); un acto de nominar que ratificaría la legitimidad de la posesión territorial efectiva a la que se aspira. Otra razón importante de la revitalización lin- 
güística se encuentra en la consciencia de la discriminación sufrida en el pasado, que fomentó la autocensura entre los mapuche-hablantes. La necesidad de adaptación contribuyó a arraigar este comportamiento, al punto tal que personas con un alto protagonismo en el movimiento confiesan haber adquirido la lengua muy tardíamente, en razón de la falta de aprendizaje en el ámbito familiar, según el testimonio de una destacada dirigente: "Yo no sabía hablar mapuche, me costaba, mi familia no había hablado en mapuche [...]; no querían [sus padres] que nosotros tuviéramos problemas en la escuela, porque ellos habían tenido muchos problemas" (Reuque Paillalef 2002: 108). A pesar de los intentos del Wallmapuben (Partido Nacionalista Mapuche) por fomentar la utilización del idioma mapuche y conferirle un lugar central en el proceso de revitalización, en tanto "nos define como nación" —-según un comunicado publicado por el periódico Azkintuwe (5/12/2008)_, la realidad no es alentadora, ya que los hablantes se circunscriben mayormente al ámbito "doméstico y rural" (ibid.). Tales circunstancias reflejan la prioridad otorgada a la acción política, aunque recientemente el Wallmapuben ha reconocido la importancia que reviste para "la lucha nacional" el uso de la lengua en el plano social y organizativo, avanzando en la confección de gramáticas y diccionarios modernos ${ }^{19}$ y en el proyecto de fundación de una Academia de la Lengua Mapuche, "así como [en] la creación de nuevas palabras que permitan hablar del mundo contemporáneo desde el mapuzungun" (Azkintuwe, 5/12/2008). Esto último no carece de relevancia, ya que la lengua, como otros elementos de la cultura, debe reacomodarse al contexto histórico en el que se desenvuelven sus hablantes. Es sabido que todos los idiomas evolucionan y adoptan nuevos vocablos, mucho más si se consideran, como en el caso mapuche, las urgencias que imponen las aspiraciones nacionalistas y la confección de sus estrategias discursivas, que incorporan conceptos ajenos a la cultura mapuche; aspecto este que no deja de plantear tensiones entre la tradición y la adopción de modelos propios del universo winka.

Sin embargo, junto con la lengua, las manifestaciones artísticas u otros elementos asociados a lo "folklórico" tratan de ser capitalizados por el Gobierno respectivo, que busca así eludir el terreno de las aspiraciones políticas mapuches (Beccaría Sacco 2008: 229). En general, las expresiones culturales de los grupos étnicos suelen ser el ámbito propicio para las actuaciones estatales, que proyectan de este modo una imagen de aceptación de la multiculturalidad en la línea de lo políticamente correcto.

\footnotetext{
${ }^{19}$ En 2006 se logró un avance importante con la publicación de la primera Gramática Básica de la Lengua Mapuche, elaborada por profesores de la Universidad Católica de Temuco con financiación de la CONADI (Comisión Nacional de Desarrollo Indígena): http://www.uct.cl/boletin/index.php?op=ver_noticia\&idn=921.
} 
Dentro del proceso de reafirmación identitaria, la recuperación de la memoria colectiva se ha plasmado en la creación del Centro de Estudios y Documentación Mapuche Liwen: otro paso significativo, en cuanto a las implicaciones del hecho de retener y acumular información, rescatar la memoria colectiva para ofrecer su propia versión del devenir histórico y reposicionar lo mapuche en los imaginarios nacionales. Hay en ello la intencionalidad de recuperar una "historicidad" (Bechis 2008: 25), negada por las políticas asimilacionistas, a través del rescate de la memoria oral, de tradiciones y de gestas, a pesar de que el propio pueblo mapuche "a veces recuerda, a veces olvida su pasado" como estrategia de supervivencia en contextos adversos (Hernández 2003: 48).

Los mapuches intervienen activamente en la interpretación de su origen y trayectoria como "pueblo" (etnogénesis), cuestionando las "historias oficiales” o hegemónicas (Bengoa 2007: 13) y polemizando con las posiciones y marcos referenciales que ofrecen los estudiosos de diferentes disciplinas. En el proceso de reafirmación identitaria es relevante la intervención de profesionales mapuches (como antes señalara, antropólogos e historiadores especialmente, algunos de ellos miembros de la comunidad académica), cuyos escritos, difundidos a veces por la prensa — no sólo étnica-, suelen arrancar con una semblanza de los orígenes históricos del "conflicto mapuche". Sin embargo, en fuentes de este tipo se puede topar con la omisión del periodo colonial español en la cadena de situaciones de opresión ejercida por los winkas, tal vez por las razones antes expuestas respecto de la autonomía territorial que los pactos de la época hispánica garantizaron a los mapuches. Para ilustrar sobre ese olvido o quizá omisión consciente, me remito a la reciente nota periodística de un antropólogo mapuche, en cuyo repaso a la trayectoria de las relaciones mapuche-winka en Chile comenzaba expresando que:

La historia empieza con la invasión del ejército chileno, los grupos de poder y la burguesía agraria del siglo XIX, que incorporó por la vía violenta el territorio ancestral mapuche y permitió, a su vez, culminar con el proceso de formación del Estado chileno (Millamán Reinao 2008: 24).

En la recomposición de su historia, los mapuches denuncian la política de asimilación, el olvido y la exclusión, que significaron para ellos la anulación de sus características étnicas y lingüísticas diferenciales bajo el denominador común de la chilenidad ${ }^{20}$ o argentinidad. De ahí que todo acto

\footnotetext{
${ }^{20}$ La presión homogeneizadora del Estado chileno movió a muchos de los mapuches residentes en centros urbanos a solicitar el cambio de apellidos, borrando así un signo clave de la alteridad. Hacia 2002, unas treinta mil personas de origen mapuche habían iniciado sus trámites con este fin (Samaniego Mesías y Ruiz Rodríguez 2007: 26).
} 
de reafirmación identitaria — como el de ser los propios narradores de la trayectoria de su nación - se convierta en un paso adelante hacia la completa "descolonización”. Un ejemplo de ello es el libro ¡Escucha, Winka! (Caniuqueo et al. 2006) ${ }^{21}$, cuyos autores cuestionan la visión eurocentrista de algunos antropólogos, aunque ponderan al mismo tiempo la labor de un etnógrafo de comienzos del siglo XX que tuvo la virtud de recoger testimonios directos de caciques de la Araucanía chilena ${ }^{22}$, dando lugar así a "una historia araucana escrita por araucanos" (Guevara 1913: 3), sin finalmente poder resistirse a los prejuicios winkas para calificar a aquellos indígenas como "un pueblo inferior" (ibid.: 5) y trazar la antítesis entre sus poblaciones (reducciones) y los "centros civilizados" (ibid.: 13).

El rescate del pasado mapuche se complementa con otras actuaciones, nada irrelevantes para la lectura del fenómeno de construcción de la nación. Me refiero, por un lado, a las demandas mapuches de restitución de restos humanos de ese origen que se conservan en el Museo de Ciencias Naturales de La Plata (Buenos Aires, Argentina) ${ }^{23}$, en concreto del cráneo de Calfucura, un famoso líder de la región Arauco-pampeana en el siglo XIX; y, por otro lado, al reclamo, por el Lof [comunidad] Mapuche Felipín, de piezas arqueológicas (vasijas, puntas de flecha, boleadoras y otros utensilios) incautadas a un estanciero de Zapala (provincia argentina de Neuquén) que pretendía traficar con ellas (Azkintuwe, 2/12/2009) ${ }^{24}$. Ambas reclamaciones son significativas: en el primer caso, en orden a cuestionar la narración de un pasado nacional que presentó la guerra de exterminio contra los pueblos de Patagonia ("Campaña al Desierto") como una acción civilizadora contra la barbarie y, en el segundo, más allá de la denuncia de un comercio ilícito de objetos de valor arqueológico, por simbolizar un gesto en contra de nuevas apropiaciones, ya materializadas en las colecciones de museos estatales o provinciales. Estas instituciones conservadoras del patrimonio suponen en sí mismas una organización o narración de la historia nacional conforme a los principios que sustentaron su construcción en el

${ }^{21}$ Véase la reseña de este libro en Morales (2007).

22 Para elaborar su obra Las últimas familias y costumbres araucanas (1913), el etnógrafo Tomás Guevara contó con la ayuda de varios caciques que recompusieron, a través de sus relatos, la historia de treinta y tres familias mapuches del Valle Central, hoy integrado en la IX Región de Chile (1913: 3).

23 En el Museo de la Plata (que incluye también secciones de Antropología y Arqueología) se conservan, además, miles de restos fosilizados de indígenas de la Patagonia (D. Badenes. "Trofeo de guerra". Centro de Estudios "Miguel Enríquez": http:// www.archivochile.com/Chile_actual/02_pueb_orig/chact_po0119.pdf. El Museo de La Plata.

24 "Comunidad mapuche reclama por saqueo y tráfico de piezas arqueológicas", Azkintuwe - Neuquén, Wallmapu - 02 / 12 / 09 (http://www.azkintuwe.org/dic021.htm). 
siglo XIX; es en este marco donde sería posible, a la luz de los planteamientos de Anderson acerca de la significación de los museos (1993: 249-257), interpretar los reclamos mapuches sobre elementos que forman parte de su patrimonio cultural como una especie de contra-discurso hegemónico.

En la senda narrativa de la nación, la prensa étnica juega un papel crucial, sobresaliendo en este aspecto el periódico bimensual Azkintuwe (citado en estas páginas), fundado en Temuco en 2003 como un órgano de prensa "nacional" para todo el espacio del Wallmapu, es decir, los territorios reivindicados por los mapuches en Argentina y Chile (Beccaría Sacco 2008: 228). En dicha publicación, la procedencia de la noticia se indica con el nombre en lengua originaria de las diferentes regiones que componen la nación mapuche; así, por ejemplo, "Puelmapu", si se trata de sucesos relacionados con los mapuches de Argentina. Por lo demás, destaca su apuesta por "la reconstrucción de aquella vieja utopía del país mapuche" (énfasis añadido), una anhelada meta frente a la cual se alza la descalificación de un miembro del Gobierno chileno, que la define, recurriendo al mismo concepto, como proyecto "utópico" 25 . Por otra parte, la tradición centralista del Estado chileno se erige como un impedimento sólido para el reconocimiento de una región autónoma; en el caso argentino, con mayor peso del federalismo histórico, existe una resistencia similar, aunque basada principalmente en razones de orden demográfico (Hernández 2003: 74).

Otra de las particularidades que identifican al movimiento de revitalización mapuche es su discurso en defensa del medio ambiente, un rasgo que comparte con la mayoría de los pueblos indígenas que hoy hacen oír su voz en el Continente. Se trata de un elemento identitario negociado, producto de la globalización del pensamiento ecologista. A nadie escapa que en las comunicaciones de los movimientos étnicos se recurra usualmente al argumento del respeto de los pueblos originarios por la naturaleza, que enlaza con el concepto de desarrollo sostenible. Los programas reivindicativos de los movimientos indígenas han sabido conjugar muy bien este argumento con el reclamo de sus derechos colectivos, conformando así un discurso "etnoecologista" (Bengoa 2007: 83, 135). Este rasgo ambientalista del movimiento de revitalización posiciona a los mapuche — como a otras etnias de América $^{26}$ - en un plano de acción común con organizaciones ecologistas y

${ }^{25}$ Declaraciones al diario El día de José A. Viera-Gallo, ministro de la Presidencia en Chile, con relación a las aspiraciones mapuches de obtener un estatuto similar al de los vascos y catalanes en España (http://www.diarioeldia.cl/index.php?option=com_ content\&task= view\&id=31652\&Itemid=167).

${ }^{26}$ Particularmente, con ocasión de asistir a la VII Reunión de Antropólogos de MERCOSUR en Porto Alegre, en julio de 2007, pude apreciar estas connotaciones en los discursos de líderes guaraníes que habían sido invitados a conferenciar en el marco de 
movimientos antiglobalización, los cuales levantan sus protestas frente a los desmanes del capitalismo global, que a la explotación secular de países y pueblos sumó la acción "depredadora" del medio ambiente (ibid.: 83). La incorporación de los principios del ecologismo fortifica y legitima los argumentos de la población mapuche en pro de la recuperación de sus territorios históricos, al denunciar los efectos contaminantes de las empresas madereras, hidroeléctricas, mineras, etc., en una estrategia que permite, además, sumar un impacto positivo y mayores adhesiones en el plano internacional.

Por lo que se refiere a la religión, si bien no constituye un factor de peso en el fenómeno de revitalización en la actualidad, sí en cambio operó como elemento aglutinante de la comunidad en épocas pasadas, en concreto durante el proceso de "re-etnificación" experimentado a fines de los años 1980 por los mapuches residentes en Santiago de Chile (Gissi 2004a). En aquel entonces, las autoridades religiosas tradicionales (los machis) fueron una figura clave para congregar a los grupos mapuches urbanos y recrear antiguas costumbres como el nguillatun (celebración ritual), contando con el apoyo de congregaciones católicas y la participación de mapuches no adscritos a esta religión. En este plano religioso, cabe destacar la adhesión de mapuches a la religión evangélica, dándose incluso el caso, como lo demuestra uno de los testimonios aportados por Gissi (2004a), de encontrarse dentro de una misma familia miembros de ese credo y practicantes católicos. Por otra parte, la expansión del pentecostalismo entre las clases populares chilenas tuvo su caldo de cultivo - como en otras regiones del Continente- en la situación de marginalidad y pobreza de ciertos sectores, que buscaron por la vía religiosa el remedio a la exclusión. Así, por ejemplo, la integración en el culto pentecostal de inmigrantes mapuches (procedentes de Chile y de la Patagonia) en Bahía Blanca (provincia de Buenos Aires, Argentina) en calidad de "hermanos", obró como mecanismo de inserción en la sociedad receptora (Hernández 2002); lo cual provocó un desdibujamiento de la etnicidad mapuche tras la adopción de una nueva identidad religiosa, quedando de este modo relegadas a un plano subalterno otras referencias, como el origen étnico-territorial o la lengua ${ }^{27}$. Tales comporta-

aquel evento. Entre otros muchos ejemplos, se encuentra el de los wichís del Chaco salteño (Argentina), quienes asimismo han hecho de la relación armónica con la naturaleza y la explotación racional de sus recursos una de sus señas de identidad (Van Dam 2001: 175). Sobre los argumentos ecologistas en las demandas de otros pueblos indígenas en Argentina, véase también Vom Hau y Wilde (2009), en relación con las denuncias de los diaguitas.

${ }^{27}$ Una persona de origen mapuche, "vocero" de la organización Acción Bahiense Comunitaria (formada por congregaciones pentecostales), apuntaba que sus ancestros "han sido mapuches de Chile, pero nosotros ya perdimos eso" (en Hernández 2002). 
mientos fueron censurados por los mapuches que defienden su etnicidad y se hallan fuertemente comprometidos con la lucha por los derechos políticos, atacando de "pro-yanquis" a los mapuches pentecostales (ibid.: 2002); reproches estos que, a su vez, parecen estar "contaminados" por los efectos de una militancia política en sectores de izquierda.

\section{LA DIMENSIÓN POLÍTICA DE LA REVITALIZACIÓN MAPUCHE}

En Chile, el movimiento mapuche tuvo su primera forma de expresión en los Centros Culturales que comenzaron a organizarse en 1978 en el sur del territorio, con el apoyo de la Iglesia Católica. Dos años más tarde adquirieron personalidad jurídica con el nombre de Asociación Gremial de Pequeños Agricultores y Artesanos Mapuches $A d M a p u$, expresión esta que significa "Junto a la tierra" (Reuque Paillalef 2002: 110). Aunque en estos inicios —en plena dictadura - hubo una política discriminatoria y de tintes "costumbristas" hacia los mapuches, fue precisamente bajo esa cobertura como se crearon las condiciones para comenzar a dar forma al movimiento. No obstante, las fracturas comenzaron a surgir al ponerse en marcha el proceso de división de tierras durante la dictadura pinochetista (véase nota no 16 ): "Este bichito de la propiedad privada está muy metido al interior de la gran cantidad de indígenas hoy día, que viven en las comunidades y no [= fuera de] en las comunidades" (Reuque Paillalef 2002: 129). A ello se añade la influencia ejercida por los partidos políticos desde 1983; en el marco de la politización del movimiento se desprendieron de $A d$ Mapu — de signo comunista - diversas organizaciones, luego agrupadas en la Coordinadora Futa Trawun Kiñewan Pu Mapuche, que se mantuvo hasta finales de la década de 1980.

Desde entonces se han ido perfilando y consolidando las definiciones políticas del movimiento, que reclama al Estado chileno el reconocimiento de la autonomía política mapuche ${ }^{28}$. Estas demandas, a la vez que se fundamentan en la existencia de una nación diferenciada e históricamente poseedora de un territorio propio, implican el rechazo del modelo "unitario" del Estado chileno, entendido como un obstáculo para la convivencia con la nación mapuche (Samaniego Mesías y Ruiz Rodríguez 2007: 429-430).

En Chile, la propuesta autonomista levantó desde sus inicios la bandera de un "etnonacionalismo" o "movimiento de liberación nacional mapuche", abierto a los habitantes de este origen en Argentina (Marimán 2005). En las

${ }^{28}$ Como un ejemplo cabal de autogobierno indígena, Bengoa (2007: 145) cita el caso de los Inuit de Groenlandia, que gozan de la "más antigua y desarrollada" autonomía. 
líneas programáticas autonomistas se hacía hincapié en la diferencia entre "identidad étnica mapuche" y "existencia nacional mapuche": la primera constituyendo el fundamento de esta última, aunque la continuidad de una etnia depende finalmente de la posesión de un espacio territorial propio, es decir, que la existencia misma de los mapuches como grupo étnico diferenciado queda supeditado a su reconocimiento como nación (Naguil 2005). La reivindicación del pasado étnico halla su más importante justificación en el disfrute de una autonomía territorial en los siglos coloniales, un derecho del que el pueblo mapuche fue privado por el Estado-nación en el siglo XIX, sufriendo por añadidura los efectos de una asimilación forzosa que lo condenó a la marginalidad y a la pobreza. El reclamo de la etnicidad, como ha señalado Hobsbawm (2000: 176) en relación con los fenómenos nacionalistas europeos (y dentro de ellos, al caso vasco), es "una forma de llenar los contenedores vacíos del nacionalismo", lo que sería válido para las nacientes repúblicas criollas que, para desprenderse de los lazos coloniales, recurrieron a un glorioso pasado indígena ${ }^{29}$ como seña de identidad, para luego excluir a los naturales al desarrollar el proyecto liberal de nación.

Si bien en la actualidad las tradiciones étnicas son el elemento articulador de las reivindicaciones mapuches, en éstas convergen factores ajenos a su universo cultural, como lo es su propuesta de autodeterminación —en la que se tiene como referente el proceso español- o bien la elección de la vía política a través de la constitución del Partido Nacionalista Mapuche, que supone la sujeción al marco partidista chileno. Aunque relativos a la descolonización africana, los conceptos de Fanon (2000 [1963]) resultan en este punto oportunos: "Los esfuerzos del colonizado por rehabilitarse y escapar de la mordedura colonial, se inscriben lógicamente en la misma perspectiva que los del colonialismo" (2000: 80).

La aspiración de autogobierno y libre determinación del pueblo mapuche se apoya en discursos de reafirmación identitaria, que exponen el argumento de una diferencialidad étnica ignorada y sepultada por el modelo de "nación hegemónica" y unitaria impuesto en Chile y Argentina tras la emancipación de España (Bengoa 2007: 13). Bajo tales proclamas subyace la idea de "ciudadanía diferencial" en contra de una "universal" (Young 1990) en la que se desconocen las particularidades étnicas y se favorece la exclusión (en Mariotti 2004: 274).

Los primeros planteamientos autonómicos se remontan a 1990, año en que el Centro de Estudios y Documentación Mapuche Liwen publicó el documento "Pueblo Mapuche, Descentralización del Estado y Autonomía

\footnotetext{
${ }^{29}$ Incluso en el Chile de hoy, es la figura "literaria" (Lautaro) de las páginas heroicas del Arauco la que se enarbola como símbolo de identidad nacional (Ancán Jara 2003: 26).
} 
Regional", que constituyó la primera propuesta "sistematizada" de autonomía. Se anunciaba como un proyecto de país "pluriétnico" — no excluyente con relación a la población no mapuche ${ }^{30}$ - en torno a los conceptos básicos de nación, autonomía regional, autogobierno y descentralización del Estado. Presentado en plena transición política, dicho documento no dio los resultados esperados, debido sobre todo a la debilidad de una posición autonomista que no logró enfocar la problemática mapuche como una "cuestión nacional", junto a otros factores como la desarticulación de las organizaciones y la cooptación de líderes por parte del Estado chileno (Naguil 2005).

Desde aquel antecedente ocurrieron cambios significativos en lo que se refiere a una mayor concienciación sobre los derechos políticos como "nación", a fin de avanzar hacia el autogobierno. En 2005 se reactivó la formulación de las propuestas autonómicas, con vistas a la constitución del "País Mapuche" (Wallmapu). Dada la fragmentación del territorio en el que habita esta etnia, las nuevas proclamas insistían en la importancia de desmantelar el "paradigma estatal territorial", otorgando primacía a la adscripción identitaria en la conformación del Wallmapu, dividido esencialmente en dos grandes subregiones: Ngulumapu o región oeste (Chile) y Puelmapu o región este (Argentina). En la base de este planteamiento nacional se encuentra el acomodo de la nueva nación en un Estado plurinacional, superando el simple reconocimiento de su carácter pluriétnico. Por otro lado, al considerar el modelo autonómico español como válido, se descartaba la "vía militar" para consolidar la nación, concebida en términos no excluyentes, con la incorporación de los no mapuches; se llegó a proponer incluso la aplicación del gentilicio "mapuche" (Marimán 2005), común para todos los habitantes de ese país imaginado.

Finalmente, la formación de un partido representativo de los mapuches - para ellos, un instrumento indispensable para la cohesión étnica y el reconocimiento como nación- (Marimán 2005) se concretó en 2006 con la presentación pública de su programa. Nació así el Partido Nacionalista Mapuche (o Wallmapuben: "Compatriotas del País mapuche"), que propuso la adopción de un idioma oficial —el mapuzungun - con el compromiso de revitalizarlo progresivamente al tratarse de un signo de identidad de la comunidad. Al año siguiente se cumplió en Temuco (noviembre 2007) la inscripción formal en el Servicio Electoral (Azkintuwe, 23-11-2007) para

\footnotetext{
${ }^{30}$ No obstante, en los territorios más plenamente identificados como mapuches, la demarcación de fronteras étnicas está presente en las referencias a la población blanca con el término de "colonos", acentuando así su condición de extranjeros que han venido a apropiarse de sus tierras.
} 
obtener su legalización y reconocimiento como nueva entidad política dentro del marco legal chileno.

Al día de hoy, al cabo de casi dos décadas de la primera propuesta autonomista, desde la dirigencia del Partido Nacionalista Mapuche se destaca el cumplimiento de sus principios programáticos en lo referente a la creación de un ente político plural, integrador de los diferentes sectores socioeconómicos de la población mapuche, tanto del ámbito urbano como del rural, figurando entre sus componentes profesionales y técnicos de diferentes ramos, campesinos, amas de casa, etc. La incorporación al partido de "técnicos y profesionales", especialmente historiadores ${ }^{31}$ y antropólogos constituye la principal baza de dicho partido, con vistas a contar con un asesoramiento apropiado sobre la historia mapuche, de cara a planteamientos estratégicos y formulación de discursos identitarios como sostén de las aspiraciones autonómicas. Por lo demás, la formación política mapuche (PNM) se define hoy como "un partido territorialista más que étnico, somos nacionalistas del territorio, del Wallmapu, del territorio que queremos gobernar, del territorio donde queremos conquistar políticamente a una mayoría y que aspiramos transformar en el hogar nacional de nuestro pueblo" (Quilaqueo 2009).

El PNM despierta el rechazo de los sectores de derecha, que tachan las propuestas nacionalistas mapuches de "desintegradoras de la unidad nacional", un discurso que tiende a disparar las alarmas, alentadas por órganos de prensa conservadores como El Mercurio (Estrada 2006) ${ }^{32}$. La situación exactamente inversa se vive en la vecina Bolivia, con una población mayoritariamente indígena que apoya la gestión de Evo Morales, reelegido en diciembre de 2009 bajo el lema de la unidad frente al "caos" representado por las ambiciones autonomistas de algunas regiones.

En la actualidad, la existencia de diferentes niveles en la organización política mapuche (local, regional, nacional) refleja un complejo entramado de relaciones, que dificulta la concreción de los reclamos comunitarios (Latta 2005: 167). En lo relativo a este ámbito, se ha destacado la "debilidad política" de muchas comunidades, como es el caso de las que se vieron afectadas por las represas hidroeléctricas de Endesa ${ }^{33}$. En este conflicto, las prác-

31 Es el caso de Víctor Naguil, autor citado en estas páginas.

32 También desde este medio periodístico se llegó a denunciar la Ley 19.253 (1993), invirtiendo el sentido de los discursos al hablar de "desigualdad" ante la ley en favor de los mapuches (Samaniego Mesías y Ruiz Rodríguez 2007: 437).

33 La Ley 19.253, sobre comunidades indígenas, legitimó a éstas como forma de organización local, reconocimiento que se plasmó en un modelo "occidental" que fracturó los principios tradicionales (Latta 2005: 168), ya que es el Estado quien fija las bases para la formación de comunidades (que adquieren la condición de tal con la "voluntad" 
ticas del poder empresarial (la negociación individual con cada familia afectada por la ocupación de tierras) se han visto beneficiadas por la desarticulación de las instancias locales con las organizaciones regionales o nacionales, frente a las que se encuentran en desventaja en virtud de su aislamiento, que conlleva un difícil acceso a los medios de difusión y a la interacción con otros agentes políticos y sociales (Latta 2005: 167). No obstante, en la esfera local los mapuches han conseguido ciertos avances, como la conquista del gobierno en ocho municipios del sur de Chile, que cuentan ya con un alcalde indígena; esto no sólo ha tenido un impacto positivo en lo que incumbe a la revitalización étnica sino también en el campo de la salud y la educación, mediante la implementación de programas interculturales, aunque no así en las relaciones con la población no mapuche, que mantiene sus recelos ante esta nueva realidad (Bengoa 2007: 21). A su vez, en Argentina se concretó recientemente la fundación del "primer municipio indígena" (Ranquel, en la provincia de San Luis), administrado por un lonko y constituido por un territorio de más de 60 mil hectáreas otorgadas por el gobierno provincial (La Nación, 16 de agosto de 2009).

Frente a los intentos de cohesionar fuerzas en un partido representativo del mundo mapuche, se erige el inconveniente de la "desarticulación" de los diferentes movimientos (Latta 2005: 179) y asociaciones creadas en Chile y Argentina. En esta última, en gran medida bajo el influjo de cierta historiografía, el imaginario nacional relaciona la presencia de poblaciones mapuches en algunas provincias patagónicas con las "invasiones" araucanas procedentes de Chile. Durante mi estancia en Argentina en agosto de 2009, y a propósito de las movilizaciones mapuches en el país vecino, oí a un universitario winka de la provincia de Neuquén referirse a los mapuches como "invasores" que sólo buscan "obtener tierras"; una percepción, por lo demás, generalizada entre chilenos y argentinos. El testimonio de este joven nos remonta a la llamada "araucanización de las pampas"; es decir, a la "supuesta" expansión transcordillerana de araucanos agricultores chilenos desde el siglo XVI para asentarse en zonas habitadas por grupos cazadores y recolectores (pampas o tehuelches), adoptando el uso del caballo y volviéndose saqueadores de los asentamientos ganaderos pampeanos (Kropff 2005: 107). El concepto de "araucanización" fue enarbolado por el "discurso hegemónico nacional” para legitimar la conquista de Pampa y Patagonia (ibid.), habiendo sido definido como una construcción intelectual iniciada

del tercio de sus habitantes). En virtud de la citada ley, Endesa debió negociar con cada una de las comunidades pehuenches afectadas por la represa hidroeléctrica Ralco, a fin de permutar sus tierras por otras fuera del embalse, dado que parte del territorio pehuenche iba a ser inundado por las obras (Latta 2005: 173; Mariotti 2004: 268). 
por una línea de pensamiento antropológico en Argentina (años 1930) ${ }^{34}$; construcción que al presente reproducen algunos medios de comunicación y que refuerza las fronteras que en el siglo pasado dividieran al pueblo mapuche al constituirse las naciones de Chile y Argentina. El fenómeno puede ilustrarse a través de la noticia publicada por el diario argentino La Nación (16 de agosto de 2009) sobre la presencia de "activistas mapuches chilenos" en Neuquén para intervenir "en los conflictos en campos argentinos" (énfasis añadido), que sugiere la idea de una infiltración o injerencia extranjera en cuestiones que competen al ámbito "nacional".

En lo que incumbe a Argentina, actualmente existen organizaciones mapuches autónomas en Chubut, Río Negro y Neuquén (Kropff 2005). En esta última provincia se constituyó la Confederación Mapuche Neuquina, con un fuerte protagonismo en el proceso de recuperación de tierras y en otras actuaciones reivindicativas, tales como el ya citado reclamo de piezas arqueológicas mapuches. En agosto de 2009, por ejemplo, se difundió la sonada noticia de la "toma" de un hotel de lujo montado por un empresario suizo en terrenos cuyos derechos de propiedad son reclamados por los mapuches — de ahí el rechazo al término "toma" de tierras-, previendo la Confederación Mapuche Neuquina establecer en esas instalaciones una "universidad intercultural" a través de un convenio con la Fundación Madres de Plaza de Mayo (La Nación, 16/08/09). Al igual que en Chile, el movimiento mapuche del Puelmapu [Argentina] interactúa con los organismos defensores de los Derechos Humanos, y asimismo con otros actores, como los partidos políticos convencionales, como es el caso del $\mathrm{ARI}^{35}$ (partido opositor al Gobierno de Argentina), uno de cuyos dirigentes, diputado nacional y antes abogado de la Confederación Mapuche Neuquina, aparece involucrado en cuestiones tales como el reclamo de tierras (La Nación, 16/08/2009), hecho que no oculta la búsqueda de un rédito político.

El ingreso de líderes del movimiento a la dinámica partidista ha desatado no pocos desacuerdos, hecho que refleja además las nuevas circunstan-

\footnotetext{
${ }^{34}$ Entre quienes defienden hoy este concepto se encuentra el investigador Rodolfo Casamiquela, según el estudio de D. Lenton sobre los "araucanos de Argentina y la discursividad nacionalista" (en Kropff 2005: 107). En 2005 Casamiquela fue acusado por jóvenes mapuches de Bariloche (Neuquén, Argentina) de sostener una postura "racista" en sus explicaciones sobre el poblamiento de Patagonia, otorgando la condición de "argentinos" a los techuelches y de "chilenos" a los mapuches, cuando "ambos pueblos, son preexistentes a los Estados citados, respectivamente", según denunciaba un comunicado de la Comunidad del Limay, en adhesión a las manifestaciones y protestas contra el académico (Boletín Nortino Rebelde, 3 de agosto de 2005, en http://nortinorebelde. blogcindario.com).

35 Partido liderado por la dirigente Elisa Carrió, que desarrolla una activa oposición al Gobierno de C. Fernández de Kirschner.
} 
cias en las que, tras la dictadura, comenzó a desenvolverse el activismo mapuche: si durante la presidencia de Allende muchos se adhirieron a la militancia de izquierda - quedando la identidad indígena diluida bajo el común denominador de "campesinos"-, al cerrarse la época pinochetista la lucha mapuche entró a focalizarse en la defensa de su identidad y autonomía frente al capitalismo global (Buendía 2003). Entre los mapuchepehuenches del Alto Bío-Bío, por ejemplo, la política es percibida como un campo de acción propio de los winka (Latta 2005: 186). A su vez, un líder mapuche, ex miembro del Consejo de Todas las Tierras ${ }^{36}$ en la década de 1990, sostenía que "los partidos [los] dividen", aludiendo a las fracturas surgidas en el movimiento a raíz de la adhesión a diferentes líneas políticas, entre ellas el socialismo y el comunismo (en Martínez Neira 2008: 144). Una visión similar refleja el testimonio de la dirigente Isolde Reuque con relación a la injerencia de la Democracia Cristiana y del Partido Comunista en el movimiento: "[...] yo creo que los partidos políticos definitivamente quisieron imponerse o manejar el movimiento Mapuche" (Reuque Paillalef 2002: 143$)^{37}$.

En lo que respecta a la naturaleza y evolución del movimiento nacionalista mapuche, las circunstancias antes reseñadas inducen a reflexionar sobre la incidencia de la participación en el marco político convencional, lo que supone asumir las reglas de juego propias de la política chilena y la aceptación de una nueva forma de liderazgo en contradicción con las tradiciones ancestrales mapuches que, aunque alteradas por los procesos de dominación winka del siglo XIX, han sido en parte rescatadas por muchas comunidades.

A través de la acción política la cuestión mapuche ha ganado un importante espacio en el escenario nacional y también más allá de sus fronteras, como lo demuestra el impacto internacional de sus reivindicaciones (que ha supuesto, por ejemplo, la cimentación de lazos con partidos nacionalistas en España). Si bien esta acción política no despierta simpatías entre los sectores más comprometidos con lo étnico, es dable detectar algunas contradicciones; así por ejemplo, el líder de la Coordinadora Arauco Malleco

${ }^{36}$ El Consejo de Todas las Tierras se formó con un grupo de disidentes de $\mathrm{Ad}$ Mapu (de orientación comunista), que proyectaron al mismo tiempo la organización de "tribunales mapuches" (Martínez Neira 2008: 144-145; Samaniego Mesías y Ruiz Rodríguez 2007: 429).

37 En el caso del Partido Comunista, el objetivo fue capitalizar el "dinamismo" del movimiento mapuche para ampliar las bases sociales de dicha organización política, según la dirigente Isolde Reuque; a la vez que su esposo se refería a los intereses partidistas como causantes de la "ideologización del movimiento mapuche" (Reuque Paillalef 2002: 146). 
de Chile, a la vez que rechazaba cualquier participación en política, defendía una autonomía como la de vascos y catalanes ${ }^{38}$. Estas circunstancias llevan a reflexionar acerca de lo que Chatterjee (2000: 152) ha señalado sobre los nacionalismos periféricos del siglo xx, modelados sobre los "nacionalismos oficiales" con elecciones, organización partidista y otras expresiones propias de los nacionalismos populares del siglo XIX. En el caso mapuche, su seguimiento de modelos autonómicos nacidos en el contexto europeo, ¿es susceptible de ser explicado, a su vez, por lo que Boccara ha definido (1999: 28-29) como "lógica mestiza", que conduciría a la reestructuración de la identidad colectiva asumiendo los retos del presente? Probablemente sea uno de los caminos para entender ciertos aspectos de la revitalización mapuche, mediante la que este pueblo continúa su curso en la historia.

\section{EL ESTADO, OTROS ACTORES Y LA CUESTIÓN MAPUCHE}

Las políticas públicas constituyen un factor relevante en la evolución de la cuestión mapuche. Las prácticas estatales, como ocurrió en el proceso de división de las tierras en Chile, han fomentado la desarticulación entre las familias de una comunidad, lo que también ha podido observarse en las negociaciones de Endesa con los afectados por el Plan hidroeléctrico de Ralco, que contó con la aquiescencia del Gobierno chileno.

La gestión de los temas indígenas y en especial de la cuestión mapuche por parte del Gobierno de Chile se canaliza mediante la CONADI (Corporación Nacional de Desarrollo Indígena), que, como todo ente estatal, promueve en un sentido políticamente correcto el discurso de la multiculturalidad, traducida en una suerte de etnicidad dirigida, que apunta a auspiciar las manifestaciones culturales de los pueblos "originarios" (en el caso aquí estudiado, la revitalización de la lengua mapuche-williche, la gastronomía, las artesanías, etc. ${ }^{39}$ ) en tanto no signifiquen un peligro para el modelo de Estado unitario que rige en Chile. En este sentido, una buena muestra la constituye el programa "Orígenes", implementado por la CONADI con fondos del Banco Interamericano de Desarrollo (BID) y enmarcado en la "política de nuevo trato" promovida por los Gobiernos de la Concertación; en

\footnotetext{
${ }^{38}$ Noticia de la agencia EFE, 13/11/2009 en: http://www.kilapan.entodaspartes.net/ spip.php?article452. La Coordinadora Arauco Malleco mantiene una posición contraria a la de la Alianza Territorial Mapuche, que se muestra proclive a las negociaciones con el Gobierno chileno.

39 Véase como ejemplo los proyectos de "revitalización de la cultura mapuche" en Lago Ranco, promocionados por la CONADI en 2008: http://www.conadi.cl/noticia 180608_3.html.
} 
suma, se trata de lo que Latta (2005) ha llamado "proyectismo", es decir, la puesta en marcha de iniciativas para promover la educación y la sanidad, la formación de líderes (es de suponer que con arreglo a las premisas del capitalismo) o las mejoras en la producción agrícola. En el plano de la productividad en especial, las políticas públicas tienden a la asimilación de los mapuches a la lógica del mercado, como quedó demostrado en el conflicto con los grupos pehuenches del Alto Bío-Bío; se trata de un intervencionismo estatal en armonía con los esquemas del neo-liberalismo económico, percibido desde el activismo mapuche como una seria amenaza para la autonomía comunitaria (Latta 2005: 165-167).

En el caso de Argentina, funciona el Instituto Nacional de Asuntos Indígenas (INAI), cuyos derroteros difieren del órgano chileno (CONADI) a la vista de actuaciones tales como la concesión de la personería jurídica a comunidades indígenas mapuches de la región patagónica (Hernández 2003: 55-56). Sin embargo, cabe señalar que la constitución de comunidades requiere una suma de condiciones legales, lo que supone de por sí la injerencia de los poderes públicos en la esfera indígena, definiendo otra manifestación de etnicidad dirigidd ${ }^{40}$ a la vez que genera conflictos en el plano jurídico-institucional entre el Estado y las provincias: en este último ámbito, se ha tendido a restringir el acceso de los indígenas a la propiedad de la tierra en áreas con recursos clave (hídricos o energéticos, por ejemplo). Además, la necesidad de disponer de interlocutores en las relaciones con las instancias nacionales o provinciales resquebraja la capacidad de mantener las solidaridades y decisiones colectivas: al presentarse como "portavoces" de la comunidad los activistas, caciques o miembros del concejo comunal y sus allegados por lazos de amistad o parentesco (Vom Hau y Wilde 2009: 21).

Otro cometido clave del INAI en Argentina es la implementación del "Programa de Relevamiento Territorial" (Ley 26.160, de 2006), consistente en el "registro técnico, jurídico y catastral de la situación dominial de las tierras ocupadas por las comunidades indígenas" ${ }^{11}$. Este registro se formaliza mediante dos vías diferentes: una descentralizada - ejecutada por los entes provinciales constituidos al efecto- y otra centralizada, a cargo directo del

${ }^{40}$ En este aspecto, resulta interesante la perspectiva de análisis formulada por Vom Hau y Wilde (2009: 4), que combina un enfoque de los movimientos sociales y su lucha por una ciudadanía dirigida "desde abajo" y de un modelo de ciudadanía conducida "desde arriba" por el Estado.

${ }^{41}$ Ministerio de Desarrollo Social [Argentina]. Instituto Nacional de Asuntos Indígenas (INAI). Tierras y Registro Nacional de Comunidades Indígenas - Programa de Relevamiento Territorial: www.desarrollosocial.gov.ar. [Nota: el término "relevamiento" es de uso habitual en Argentina, como sinónimo de registro o recogida de datos.] 
INAI, lo que genera un desarrollo desigual determinado por las peculiaridades locales, entre las que desempeñan un papel crucial las presiones de latifundistas: como puede constatarse en el caso de las comunidades diaguitas y lules en Tucumán (en la región del noroeste argentino), afectadas por los intereses de esos sectores ${ }^{42}$.

Con el tiempo, las luchas mapuches han ido convergiendo con las de otros sectores, lo que ha contribuido a reforzar y difundir sus reivindicaciones. Entre estas instancias se encuentran los movimientos en defensa del medio ambiente, los organismos en favor de los derechos humanos (por solidaridad con los dirigentes mapuches encarcelados), otros movimientos de revitalización y también ONG. En cuanto a éstas, sin embargo, a menudo actúan como fieles ejecutoras de los planes desarrollistas del BID, considerados como un mecanismo de "asimilación" de los mapuches a las directrices del modelo liberal mediante proyectos y subsidios, en un proceso que ha generado disputas entre las diferentes asociaciones mapuches por los recursos de la cooperación internacional (Latta 2005).

En el campo de las relaciones internacionales, la OIT es una importante referencia para el futuro del autonomismo mapuche, teniendo en cuenta las disposiciones del Convenio 169 (1989), que estableció el derecho de los indígenas a ser reconocidos como pueblos diferenciados y a ser consultados por los Gobiernos, especialmente en materias que atañen a su desarrollo; lo que significa adaptar el marco jurídico estatal para dar cabida a tales concesiones. Tanto Argentina como Chile —-más recientemente- han ratificado este convenio, aunque en el caso chileno aguarda el largo camino de adaptación de la legislación local para hacerlo realmente efectivo. En Argentina, el proceso de reconocimiento pleno — como ocurre con el otorgamiento de personería jurídica y títulos de propiedad de tierras- no está exento de situaciones conflictivas, especialmente por estar sujeto a las actuaciones en dos niveles, el nacional y el local, con las correlativas variantes en lo que respecta al marco institucional (Vom Hau y Wilde 2009).

En otro orden de cosas, son relevantes los vínculos establecidos por el

${ }^{42}$ Tucumán es una de las provincias en las que el registro territorial se encuentra avanzado, aunque en fecha muy reciente las comunidades indígenas (un total de 19 en el territorio provincial) han denunciado la existencia de sentencias judiciales de desalojo en favor de "terratenientes", contraviniendo así las disposiciones de la Ley 26.160 (2006), que declaró "la emergencia en materia de posesión y propiedad de las tierras que tradicionalmente ocupan las comunidades indígenas por el término de cuatro años" (plazo que se ha prorrogado hasta 2013); disposición por la que quedaban suspendidos durante este término de tiempo "la ejecución de sentencia y actos procesales o administrativos cuyo objeto sea el desalojo o desocupación de tierras" (ARGENPRESS.Info:http:// www.argenpress.info/2010/03/argentina-tucuman-comunidades-indigenas.html). 
Partido Nacionalista Mapuche (Wallmapuben) con organizaciones políticas vascas, en concreto con ARALAR (partido de la izquierda independentista creado en 2002, que condena la lucha armada). Con esta "fuerza política hermana" se firmó en julio de 2008 "un protocolo de colaboración mutua", según informaba Gustavo Quilaqueo, presidente del Wallmapuben, tras participar en el último Congreso Nacional de la misma ${ }^{43}$. El "hermanamiento" con la formación vasca obedecería al hecho de transitar ambas por una misma senda, la de la "liberación nacional" a través de la acción política en un marco democrático. El citado líder mapuche dejaba claro —en alusión al desarrollo autonómico español- que "no hay ningún modelo a copiar", de modo que tal alianza con un partido independentista se justificaba por la necesidad de compartir experiencias y estrategias en torno al objetivo de "conquistar poder donde se toman las decisiones políticas" y, además, porque "el proceso de solidaridad internacional con las luchas de otros pueblos oprimidos es un elemento que no podemos dejar de lado. Ser internacionalistas es un deber que tenemos como mapuches" (Quilaqueo 2009. Énfasis añadido). Este dirigente ponía de relieve las similitudes entre el proceso vasco y el mapuche, como a su vez las distancias históricas entre uno y otro, aunque su interés en señalar como rasgo compartido el ser ambos "pueblos oprimidos" parece anular la brecha entre dos historicidades diferentes, cuyas particularidades huelga destacar. Esta alusión a la "opresión" estaría sugiriendo, por otra parte, un trasvase de componentes de la discursividad reivindicatoria mapuche al caso vasco, convalidando de este modo, paradójicamente, la adscripción a un modelo de proyecto autonomista viable para el reconocimiento de la nación mapuche: "Hay por cierto diferencias geopolíticas y socioeconómicas entre los mapuches y los vascos, pero la lucha por decidir por nosotros mismos un destino nacional la compartimos y ello nos hermana. Por lo demás, la lucha política opera con ciertos códigos que son similares estés en China, Euskal Herria o en Wallmapu” (Quilaqueo 2009).

\section{CONCLUSIONES}

El rescate de las tradiciones y costumbres ancestrales, centrado esencialmente en la recuperación de los territorios ocupados históricamente, constituye el componente básico del movimiento de revitalización mapuche de

${ }^{43}$ A este IV Congreso de ARALAR, celebrado en Pamplona (Navarra, España) en octubre de 2009, fueron invitados el presidente del Wallmapuhen y otros dirigentes de este partido, como así también líderes nacionalistas kurdos, catalanes y bretones. En esta reunión, los representantes del Partido Nacionalista Mapuche entregaron a ARALAR la Wenufoye, "nuestra bandera nacional mapuche" (Quilaqueo 2009). 
las últimas décadas, siendo su objetivo último el reconocimiento de este pueblo como "nación" diferenciada por parte del Estado chileno. El reclamo de la etnicidad, que supone asumirse plenamente como mapuches (condición antes silenciada por la discriminación sufrida, tanto en Chile como en Argentina), recoge, sin embargo, elementos negociados, ajenos a las prácticas tradicionales, como resultado lógico de la dinámica interactiva con nuevos actores, en un contexto muy diferente al de su pasado étnico.

La revitalización mapuche, que constituye sin duda un fenómeno altamente complejo, tiene hoy como motor principal la lucha contra la globalización económica, manifiesta en la instalación de empresas de diverso tipo (dedicadas a la explotación de recursos hídricos, forestales o mineros en Chile, de hidrocarburos en Argentina) que han ocupado los territorios "ancestrales" de la etnia. Atendiendo a estas circunstancias, las movilizaciones mapuches frente a la expansión del capitalismo transnacional -acción en la que confluyen otros movimientos sociales - apuntan a reforzar sus demandas de autogobierno, en tanto que éste implica la potestad de autogestionar los recursos de un territorio reivindicado como propio, en armonía con un modelo de desarrollo sostenible.

A lo largo de su trayectoria en las últimas décadas, hombres y mujeres mapuches han conseguido hacerse visibles en el ámbito nacional chileno y argentino, especialmente en las áreas de mayor concentración de población de ese origen, a lo que debe sumarse el eco internacional de sus programas reivindicativos. La fuerza de sus movilizaciones, su presencia e intervención en la vida política local, en las universidades y en muchas otras esferas, como así sus logros en el plano de la reafirmación cultural, sin duda han coadyuvado a su consolidación como grupo diferenciado dentro de las respectivas repúblicas, si bien sus pretensiones nacionalistas concitan en ellas la resistencia de los sectores conservadores, que perciben tales pretensiones como atentatorias a "la integridad nacional" según estos sectores la conciben.

En orden a sus aspiraciones nacionalistas, la "cuestión mapuche" sigue abierta. La consagración del Wallmapu o "País Mapuche" está condicionada a factores tales como la fragmentación territorial, no sólo por estar esta población repartida entre los territorios de dos repúblicas sino también por el hecho de que, a pesar de existir algunas acciones coordinadas, una estrategia común a ellas parece de difícil concreción: los movimientos a uno y otro lado de la Cordillera se enfrentan a ámbitos estatales que tienen cada uno su propia organización política y marco jurídico particular. La existencia de diversas organizaciones mapuches y la falta de articulación entre las mismas, con diferente valoración respecto de las relaciones con instancias no mapuches, representa otra dificultad; a la que se agrega, en el caso de Chile, que el órgano político representativo de las aspiraciones autonomis- 
tas, el Partido Nacionalista Mapuche (Wallmapuben), aún no se encuentra oficialmente inscrito en el registro de partidos políticos.

Fuera del contexto chileno y argentino, la identificación de la realidad mapuche con el desarrollo autonómico español no resulta ajustada a la realidad histórica, contrariamente a lo dado a entender por algunos dirigentes mapuches y nacionalistas en España, especialmente en el País Vasco. El primer problema aquí es que no existió en España un proceso de colonización en los términos vividos por los mapuches. Más ejemplarizante para las aspiraciones políticas del movimiento (al menos en Chile) es el caso de la vecina Bolivia, un país cuya población es mayoritariamente indígena y que se ha erigido como un referente de peso para medir las perspectivas de que lo étnico llegue a posicionarse como fuerza nacional. Todo ello, sin negar las pequeñas conquistas parciales (como el acceso al gobierno de municipios) logradas en las regiones con una presencia mapuche importante.

No obstante, en vísperas de la celebración del bicentenario de la emancipación hispanoamericana y de la constitución de las nuevas repúblicas criollas, el fenómeno de la revitalización mapuche, como otros procesos similares del Continente, habrá contribuido a ahondar y enriquecer el análisis sobre la "invención" de tradiciones como sustento de las formaciones nacionales, cualquiera sea su índole y contexto espacio-temporal. Y, más aún, a reflexionar sobre la ruptura de una situación secular de obligada pasividad de los pueblos originarios de América por efecto de las políticas coloniales y post-independentistas. En ese resurgimiento, no bajo la denominación generalizadora de "indígenas" sino ya en su propio nombre, los mapuches y otros grupos americanos reinventan su identidad como agentes activos de la historia.

\section{BIBLIOGRAFÍA CITADA}

Ancán Jara, J. 2003. "Prólogo", en I. Hernández, Autonomía o ciudadanía incompleta. El pueblo Mapuche en Chile y Argentina: 23-28. Santiago de Chile: Naciones UnidasCEPAL.

Anderson, B. 1993. Comunidades imaginadas. Reflexiones sobre el origen y la difusión del nacionalismo. México: FCE.

Beccaría Sacco, L. 2008. "La voz originaria en las rotativas. La construcción del imaginario en los periódicos indígenas de Argentina”. Comunicación e Cidadanía 8: 221-236. (Disponible en Internet: www.observatoriodemedios.org).

Bechis, M. 2008. Piezas de etnobistoria del sur sudamericano. Madrid: CSIC.

Bengoa, J. 2007. La emergencia indígena en América Latina. Chile: FCE.

Boccara, G. 1999. "Antropología diacrónica. Dinámicas culturales, procesos históricos y poder político”, en G. Boccara y S. Galindo (eds.), Lógica mestiza en América: 21-59. Temuco: Instituto de Estudios Indígenas, Universidad de la Frontera. 
Briones, C. y A. Ramos. 2005. "Audiencias y contextos: la historia de 'Benetton contra los mapuches'”. E-misférica. Perfomance and Politics in the Americas (disponible en Internet: http://www.hemisphericinstitute.com/journal/2_1/2_1/briones.html).

Buendía, M. 2003. "Chile. El pueblo mapuche y el golpe militar". Centro de Estudios Miguel Enríquez - Archivo Chile, en http://www.archivochile.com/Pueblos_originarios/ lucha/POlucha0003.pdf.

Caniuqueo, S. et al. 2006. ¡Escucha, winka!. Santiago de Chile: LOM.

Censo Nacional de Población, Hogares y Viviendas de 2001 [Argentina]: http://www.indec. gov.ar/censo2001s2/presenta.asp.

Chatterjee, P. 2000. "El nacionalismo como problema en la historia de las ideas políticas”, en A. Fernández Bravo (comp.), La invención de la nación. Lecturas de la identidad de Herder a Homi Bhabha: 123-164. Buenos Aires: Manantial.

Encuesta Complementaria del Censo Nacional de Población, Hogares y Viviendas de 2001 [Argentina]: http://www.indec.gov.ar/webcenso/ECPI/index_ecpi.asp.

Encuesta Complementaria de Pueblos Indígenas. Resultados nacionales [Argentina]: http:/ /www.indec.gov.ar/webcenso/ECPI/pueblos/ampliada_index_nacionales.asp? $m o d e=00$.

Estrada, D. 2006. "Mapuches en busca de la autonomía". Azkintuwe 24 de Febrero de 2006.

Fanon, F. 2000 [1963]. "Sobre la cultura nacional", en A. Fernández Bravo (comp.), La invención de la nación. Lecturas de la identidad de Herder a Homi Bhabha: 77-89. Buenos Aires: Manantial.

Fernández, J. A. 2005. "Las raíces profundas del nacionalismo". Ciencias Sociales Online II (1): $75-81$.

Fernández Bravo, A. (comp.). 2000. La invención de la nación. Lecturas de la identidad de Herder a Homi Bhabha. Buenos Aires: Manantial.

Gissi, N. 2004a. "Segregación espacial mapuche en la Ciudad: ¿Negación o revitalización identitaria?". Revista de Urbanismo 9 (enero). Santiago de Chile. Publicación electrónica editada por el Departamento de Urbanismo, F.A.U. de la Universidad de Chile. (Disponible en Internet: http://revistaurbanismo.uchile.cl/CDA/urb_complex.)

Gissi, N. 2004b. "Los mapuche en el Santiago del siglo XXI: desde la ciudadanía política a la demanda por el reconocimiento". (Disponible en Internet: www.cultura-urbana.cl/ los-mapuches-en-el-santiago-del-siglo-xxi-gissi.pdf.)

Guevara, T. 1913. Las últimas familias y costumbres araucanas. Santiago de Chile: Imprenta, Litografía y Encuadernación Barcelona.

Hastings, A. 2000. La construcción de las nacionalidades. Etnicidad, religión y nacionalismo. Madrid: Cambridge University Press.

Hernández, G. 2002. "Religión e Identidad. La identidad evangélica pentecostal en un contexto migratorio de origen indígena y rural de la Patagonia argentina y de Chile, en la ciudad de Bahía Blanca", en 3er Congreso Virtual de Antropología y Arqueología. (Disponible en Internet: http://www.naya.org.ar/congreso2002/index.htm.)

Hernández, I. 2003. Autonomía o ciudadanía incompleta. El pueblo Mapuche en Chile y Argentina. Santiago de Chile: Naciones Unidas-CEPAL.

Hobsbawm, E. 2000 [1992]. "Etnicidad y nacionalismo en Europa hoy", en A. Fernández Bravo (comp.), La invención de la nación. Lecturas de la identidad de Herder a Homi Bhabha: 173-184. Buenos Aires: Manantial.

Kropff, L. 2005. "Activismo mapuche en Argentina: trayectoria histórica y nuevas tendencias”, en P. Dávalos, H. Díaz Polanco y L. Macas (eds.), Pueblos indigenas, estado y democracia: 103-132. Buenos Aires: CLACSO.

Latta, A. P. 2005. "La política mapuche local en Chile. Las comunidades pehuenche del Alto Bío-Bío. Un estudio de caso". Líder 13: 165-190. 
Marimán, J. 2005. "Una reflexión necesaria. Apuntes sobre la construcción de un partido mapuche". Azkintuwe 14 de diciembre de 2005. (Disponible en Internet: http:// www.mapuche-nation.org/espanol/html/articulos/art-109.htm.)

Mariotti, D. 2004. "El conflicto por la tierra de las comunidades aborígenes Kollas (Argentina) y Mapuche (Chile): discursos globales en escenarios locales", en N. Giarraca y B. Levy (comps.), Ruralidades latinoamericanas. Identidades y luchas sociales: 257304. Buenos Aires: CLACSO.

Martínez Neira, Ch. 2008. "Repensar la etnohistoria a partir de la experiencia mapuche". Estudios avanzados 6 (9): 141-152.

Millamán Reinao, R. 2008. "La historia oculta de los mapuches". Le Monde diplomatique en español XII, abril 2008: 24.

Ministerio de Desarrollo Social [Argentina]. Instituto Nacional de Asuntos Indígenas (INAI). Tierras y Registro Nacional de Comunidades Indígenas - Programa de Relevamiento Territorial: www.desarrollosocial.gov.ar.

Morales, R. 2007. Reseña de jEscucha, winka! Revista Austral de Ciencias Sociales 12: 159164.

Naguil, V. 2005. "Autogobierno del País Mapuche". Azkintuwe 14: 12-14. (Disponible en Internet: http://www.mapuche.info/azkin/azkin00.html.)

Quijada, M., C. Bernand y A. Schneider. 2000. Homogeneidad y nación. Con un estudio de caso: Argentina, siglos XIX y XX. Madrid: CSIC.

Quilaqueo, G. 2009. Entrevista realizada a Gustavo Quilaqueo en Santiago de Chile, 13/ 10/2009, (Enlace Mapuche Internacional: http://www.mapuche-nation.org/espanol/ $\mathrm{html} /$ articulos/art-144.htm).

Radovich, J. C. y A. Balazote. 1999. Estudios antropológicos sobre la cuestión indígena en la Argentina. Buenos Aires: Minerva.

Reuque Paillalef, R. I. 2002. Una flor que renace: autobiografia de una dirigente mapuche. Editado y presentado por F. E. Mallon. Santiago de Chile: Centro de Investigaciones Diego Barros Arana.

Saavedra Peláez, A. 2002. Los mapuches en la sociedad chilena actual. Santiago: LOMUniversidad Austral.

Samaniego Mesías, A. y C. Ruiz Rodríguez. 2007. Mentalidades y políticas wingka. Pueblo mapuche, entre golpe y golpe (de Ibáñez a Pinochet). Madrid: CSIC.

Van Dam, Ch. 2001. "Condiciones para un uso sostenible: el caso del Chaguar (Bromelia bieronymi) en una comunidad Wichí del Chaco argentino", en A. Teruel, M. Lacarrieu y O. Jerez (comps.), Fronteras, Ciudades, Estados (Tomo I): 175-208. Córdoba: Alción.

Vom Hau, M. y G. Wilde. 2009. "We Have Always Lived Here': Indigenous Movements, Citizenship and Poverty in Argentina". BWPI Working Papers 99: 1-28. The University of Manchester-Brooks World Poverty Institute (http://www.manchester.ac.uk/bwpi).

Warren, K. B. 1999. "La lectura de la historia, una forma de resistencia: intelectuales públicos mayas en Guatemala", en E. F. Fischer y R. Mackenna Brown (eds.), Activismo cultural maya: 133-152. Guatemala: Cholsamaj.

Weber, D. J. 1998. "Borbones y Bárbaros. Centro y Periferia en la reformulación de la política de España hacia los indígenas no sometidos". Anuario IEHS 13: 147-171.

Young, I. M. 1990. Justice and The Politics of Difference. Princeton: Princeton University Press.

Fecha de recepción: 8 de enero de 2010.

Fecha de aceptación: 27 de enero de 2010 